\title{
Rapid Transient Efflux of Phosphate Ions from \\ Pancreatic Islets as an Early Action of Insulin Secretagogues
}

\author{
Norbert Freinkel, Catherine El Younsi, Jerry Bonnar, and Rex M. C. Dawson \\ From the Center for Endocrinology, Metabolism, and Nutrition, and the Departments of \\ Medicine and Biochemistry, Northwestern University Medical School, \\ Chicago, Illinois 60611
}

\begin{abstract}
A B S T RACT Anionic fluxes during the membrane realignments of stimulated insulin release have not been characterized previously although cations have been implicated in stimulus-secretion coupling. We have shown that a limited packet pulse of phosphate release ("phosphate flush") begins at the same time that the first phase of insulin secretion may occur. To demonstrate this phenomenon, we have prelabeled islets, obtained from rat pancreas by collagenase digestions, by incubation with $\left[{ }^{22} \mathrm{P}\right]$ orthophosphate. When such prelabeled islets are perifused with Krebs-Ringer bicarbonate containing $0.5 \mathrm{mg} / \mathrm{ml} \mathrm{D}$-glucose, a basal rate of efflux of radioactivity is established; transfer to perifusates containing $3.0 \mathrm{mg} / \mathrm{ml} \mathrm{D-glucose}$ elicits an increased ${ }^{32} \mathrm{P}$ efflux within 1-2 min to peak values which are 7 - to 21 -fold greater than basal. The total duration of this "phosphate flush" approximates $10 \mathrm{~min}$ and exceeds the duration of the first phase of stimulated insulin secretion. With lesser concentrations of glucose, the flush exhibits dose-response relationships, and with $3 \mathrm{mg} / \mathrm{ml}$ glucose, a second flush can be elicited by restoring basal conditions and stimulating anew with $3 \mathrm{mg} / \mathrm{ml}$ glucose. The phenomenon is highly specific and can be reduplicated by other secretagogues (L-leucine) or sugars (D-mannose) which are also known to elicit insulin release but not by sugars which fail to affect insulin secretion (D-galactose, D-fructose, i-inositol, L-glucose). The efflux of radioactivity consists entirely of $\left[{ }^{22} \mathrm{P}\right]$ orthophos-
\end{abstract}

This work was presented in part at the joint Annual Meeting of The American Federation for Clinical Research, The American Society for Clinical Investigation, and The Association of American Physicians, Atlantic City, N. J., 5 May 1974 (Clin. Res. 1974. 22: 568A).

Dr. Dawson was a Visiting Scientist with the Center for Endocrinology, Metabolism, and Nutrition, Northwestern University Medical School, Chicago, Ill. His permanent address is ARC Institute of Animal Physiology, Babraham, Cambridge, England.

Received for publication 14 February 1974 and in revised form 3 June 1974. phate. Phosphate flush persists in phosphate-free media, $\mathrm{Ca}^{++}$-free media, and when insulin release is obtunded by adding $\mathrm{Ni}^{++}(2 \mathrm{mM})$ to the perifusates. Thus, efflux of $\left[{ }^{32} \mathrm{P}\right]$ orthophosphate can be dissociated from insulin extrusion, and from net influx of ionic phosphate or calcium. Membrane stabilization with $\mathrm{D}_{2} \mathrm{O}$ or $1.0 \mathrm{mM}$ tetracaine reversibly inhibits phosphate flush. Although the mechanism by which this effect occurs has not yet been established, the phosphate flush appears to constitute one of the earliest and hitherto unknown indices of the excitatory state in pancreatic islets.

\section{INTRODUCTION}

Although considerable information is available concerning the factors which are necessary for the secretion of insulin from the pancreatic $\beta$-cell, the precise sequence of events leading to release of the hormone from the stimulated gland is still far from clear (1). Studies have shown that calcium is essential for excitation of the gland and that ATP is required for the release of insulin, perhaps both for the formation of cyclic AMP and for supplying energy for the emiocytosis of secretion granules through a microtubule system. Coupled with these requirements there is evidence that stimulation of the gland causes an immediate increase in the rate of synthesis of the acidic phospholipids, especially phosphatidylinositol (2).

In early studies, Freinkel $(3,4)$ showed that in an analogous situation in which a secretory gland is transformed from "resting" to working," namely thyroid tissue treated with thyrotropin, there was an appreciable increase of intracellular inorganic phosphate and watersoluble phosphate esters. This paralleled a concurrent stimulation of oxygen consumption and glucose utilization and appeared to be one of the earliest biochemical sequelae of the thyrotropin action. An outflux of inorganic phosphate and water-soluble phosphate esters has 
also been observed during depolarization of excitable tissues such as frog sartorius muscle cells and spinal root nerve preparations (5). Since such an event might occur as a general phenomenon associated with the excitatory state we have examined the isolated islet of the pancreas in this context. Islet cells were prelabeled in vitro by an incubation with $\left[{ }^{32} \mathrm{P}\right]$ orthophosphate and then subjected to perifusion. The experiments have clearly shown that when such prelabeled islets are exposed to insulin secretagogues during perifusion, there is an immediate and substantial efflux of radioactive phosphate ions from the cells to the perifusion medium.

Use of this technique has also enabled us to examine whether the increased turnover of phosphatidylinositol previously mentioned is concerned with the excitation or secretion processes either directly or indirectly. The phenomenon itself is virtually universal in physiological situations in which cells are galvanized into heightened secretory or other activity (6). Recently we have shown that the breakdown of phosphatidylinositol by tissue enzymes (7) can be brought about by the direct schism of phospholipid into a diglyceride and a novel metabolite, inositol-1,2-cyclic phosphate (8). Clearly the possibility existed that this metabolite could be involved in the series of events necessary for insulin release, either by acting as a second messenger or by enhancing the action of cyclic AMP by phosphodiesterase inhibition. We were therefore able by the same technique to investigate whether in pancreatic islet cells stimulated to secrete insulin there was a concomitant release to the perifusion medium of inositol cyclic phosphate or its immediate catabolic metabolite, inositol monophosphate.

\section{METHODS}

Preparation of islets of Langerhans. Female albino rats weighing 200-300 $\mathrm{g}$ fed ad lib. were used in all experiments. Islets were isolated essentially by the techniques described by Lacy and Kostianovsky (9) and Lacy, Walker, and Fink (10) incorporating a modification used by MalaisseLagae and Malaisse (11) in which the exposed pancreas is injected with Hanks' solution before its removal and partial digestion with collagenase. Each donor rat was anesthetized with pentobarbital and four pancreases were processed at the same time by two workers. Cut-up pancreases from two animals were combined in Hanks' solution, and after allowing the pieces to settle, the floating fat layer was decanted and surplus Hanks' solution was removed leaving the pancreas segments in approximately $4 \mathrm{ml}$ of fluid. The suspension was warmed to $37^{\circ} \mathrm{C}$ in a water bath, $4 \mathrm{mg} / \mathrm{ml}$ collagenase (Worthington Biochemical Corp., Freehold, N. J., type IV lots 229,257 ) added, and the incubation continued with hand shaking. The digestion was judged complete when no pieces or strings of tissue were visible, and it was stopped by flooding the incubate with excess Hanks' solution. After centrifugation at low speeds the supernate together with a pink slimy layer of acinar tissue debris was removed from the top of the lower islet layer. Repeated washing was carried out by this method until the supernate was clear of acinar tissue and contained no islets.

In initial experiments the islets were concentrated and purified by preliminary fractionation on a Ficoll gradient (12). However, in later experiments this step was eliminated because even though the Ficoll had been purified by dialysis its use led to erratic insulin release, a finding independently observed by Beigelman, Shu, and Thomas (13). The preparations of islets from four pancreases were combined and suspended in Petri dishes of Hanks' solution at room temperature, and individual islets removed with the aid of a dissecting microscope using a siliconized pipette. Two workers picked out 200-400 islets between them in $1 \mathrm{~h}$. The islets were transferred to a Krebs-Ringer bicarbonate modified so that each $100 \mathrm{ml}$ contained $0.05 \mathrm{mmol} \mathrm{Na} \mathrm{HPO}_{4}$ (added as $0.1 \mathrm{M} \mathrm{NaHPO}_{4}-\mathrm{HCl}$ buffer $\mathrm{pH} 7.4$ ), $500 \mathrm{mg}$ bovine serum albumin (Fraction V, Armour Pharmaceutical Company, Chicago, Ill.), $100 \mathrm{mg}$ glucose, 10,000 U penicillin, and $10 \mathrm{mg}$ streptomycin sulfate. The islets were washed at least five times by decantation in the same medium.

Labeling of islets. The complete yield of islets was suspended in $1 \mathrm{ml}$ of the above modified Krebs-Ringer bicarbonate to which had been added $150 \mu \mathrm{Ci}$ of carrier-free $\left[{ }^{32} \mathrm{P}\right]$ inorganic phosphate. The suspension was gassed for 5 min with $95 \% \mathrm{O}_{2}-5 \% \mathrm{CO}_{2}$ and incubated for $90 \mathrm{~min}$ at $37^{\circ} \mathrm{C}$ with shaking under the same gas phase. The labeled islets were then washed 12 times using a Krebs-Ringer bicarbonate medium modified so that each $100 \mathrm{ml}$ contained 0.1 mmol $\mathrm{Na}_{2} \mathrm{HPO}_{4}, 500 \mathrm{mg}$ bovine serum albumin, $50 \mathrm{mg}$ glucose, together with the same antibiotics as described above. Analysis of 10 consecutive preparations of islets, after labeling with ${ }^{32} \mathrm{P}$ and washing, indicated that 68.8 $\pm 1.6 \%{ }^{1}$ of the radioactivity present was acid-soluble, 7.2 $\pm 0.7 \%$ had been incorporated into the phospholipid fraction and the remainder was in the nucleic acid and phosphoprotein residue. Two-dimensional thin-layer chromatography (14) showed that a majority $(73.2 \pm 1.7 \%)$ of the phospholipid labeling was in the phosphatidylinositol fraction.

Perifusion of labeled islets. Washed islets were removed, 10 at a time, and introduced into small siliconized glass vessels with less than $1 \mathrm{ml}$ medium until 100 had been accumulated. Thereafter the islets were transferred with a siliconized pipette onto $5.0-\mu \mathrm{m}$ millipore filters (Gelman) which had been placed in perifusion chambers (Millipore plastic filtration units, [Millipore Corp., Bedford, Mass.], 1 $\mathrm{ml}$ capacity) as described by Lacy et al. (10). Two perifusions were usually undertaken in each experimental run. The islets were kept moist with the same Krebs-Ringer solution during application onto each filter, whereupon the chambers were filled with the same medium, and the perifusion commenced. The same medium at $37^{\circ} \mathrm{C}$ was forced over the islets with a dual-channel peristaltic pump (Harvard Apparatus Co., Inc., Millis, Mass.) at a rate of approximately $0.8-0.9 \mathrm{ml} / \mathrm{min}$. In typical experiments the initial collections of effluent were made over 5 -min intervals for $40 \mathrm{~min}$ reducing to 3 -min intervals for $6 \mathrm{~min}$ and then 1-min intervals 4 min before any change in the perifusion medium. After the change, 14 successive 1-min collections were made followed by two 3-min and subsequent 5-min collections. Each experiment described in this paper was performed at least in duplicate or triplicate on separate occasions and with separate preparations of islets.

Counting. Portions $(0.05 \mathrm{ml})$ of each eluate collection were diluted with $10 \mathrm{ml}$ of Aquasol scintillation fluid (New

\footnotetext{
${ }^{1}$ Mean \pm SEM.
} 
England Nuclear, Boston, Mass.) and counted in a NuclearChicago Mark I liquid scintillation counter (NuclearChicago Corp., Des Plaines, Ill.).

Insulin assay. In most experiments, portions of each eluate collection were assayed for total immunologically reactive insulin by radioimmunoassay. Nine-point standard curves were prepared with rat insulin kindly supplied by Dr. D. F. Steiner (University of Chicago) and steer antiserum. Antibody-bound insulin was precipitated with polyethylene glycol as per Desbuquois and Aurbach (15). The release of total immunoreactive insulin, i.e. insulin plus proinsulin, was expressed in microunits liberated per islet per minute.

Paper ionophoresis. Ionophoresis of water-soluble phosphorus compounds was carried out on paper at $\mathrm{pH} 3.6$ using a volatile buffer (acetic acid-pyridine- $\mathrm{H}_{2} \mathrm{O}$ 10:1:289 parts by volume) and a voltage gradient of $80 \mathrm{~V} / \mathrm{cm}$ for $50 \mathrm{~min}$. The paper on the anode side of the origin was cut into $1-\mathrm{cm}$ strips which were assessed for radioactivity by scintillation counting.

\section{RESULTS}

Response to stimulation with high glucose concentration. When prelabeled islets were perifused with Krebs-Ringer containing $0.5 \mathrm{mg} / \mathrm{ml}$ of glucose, a relatively low but constant basal efflux of ${ }^{32} \mathrm{P}$ radioactivity and insulin into the perifusate was achieved after approximately $30 \mathrm{~min}$ (Fig. 1). The actual basal level of ${ }^{32} \mathrm{P}$ production in the nonstimulated state varied somewhat from preparation to preparation in a seemingly random manner which may possibly be connected with the degree of labeling of the islets in each chamber. After $50 \mathrm{~min}$, the perifusion medium was changed by dipping the intake of the pump into a fresh batch of medium. Perifusion with fresh medium still containing $0.5 \mathrm{mg} / \mathrm{ml}$ glucose did not alter the basal rate of ${ }^{32} \mathrm{P}$ efflux (Fig. 1). Contrariwise, perifusion with fresh medium

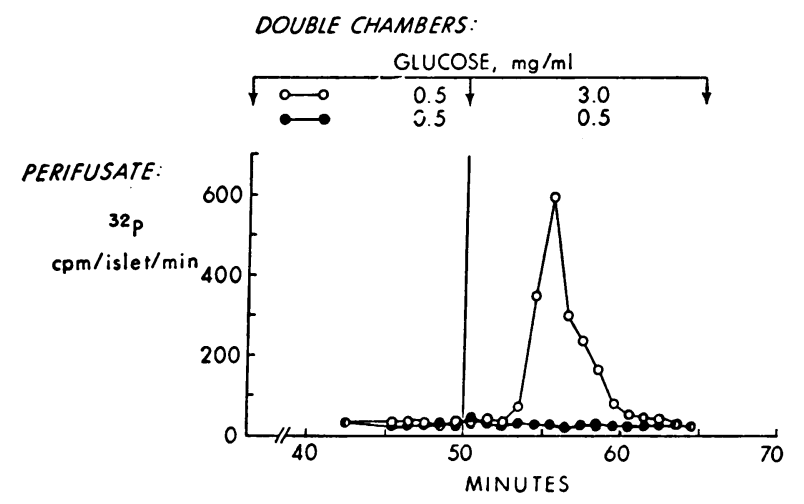

FIgUre 1 Efflux of ${ }^{32} \mathrm{P}$ during stimulation of islets with high glucose concentration: Prelabeled islets were perifused simultaneously with $0.5 \mathrm{mg} / \mathrm{ml}$ glucose in double chambers. After $50 \mathrm{~min}$, perifusion with $0.5 \mathrm{mg} / \mathrm{ml}$ glucose was continued in the chamber denoted by the solid symbols whereas perifusion with $3.0 \mathrm{mg} / \mathrm{ml}$ glucose was instituted in the chamber depicted by the open symbols. The illustration depicts absolute values from a representative experiment. Detailed analyses from 25 experiments are given in the text.

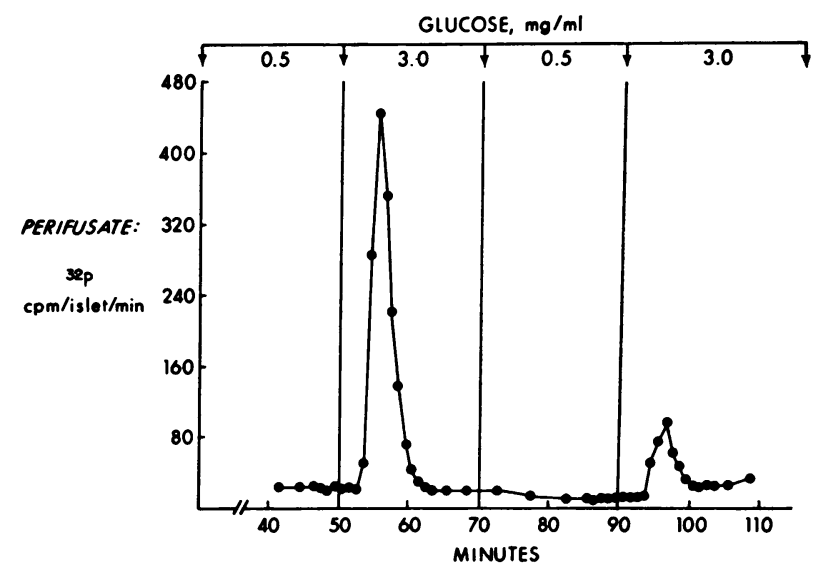

FIGURE 2 Efflux of ${ }^{32} \mathrm{P}$ during repetitive stimulation: One of three experiments is presented in which prelabeled islets were stimulated with $3 \mathrm{mg} / \mathrm{ml}$ glucose a second time (at 90 $\mathrm{min}$ ) after glucose in the perifusate had been reduced to $0.5 \mathrm{mg} / \mathrm{ml}$ (at $70 \mathrm{~min}$ ).

containing $3 \mathrm{mg} / \mathrm{ml}$ glucose resulted in a rapid pulse of radioactivity into the perifusate (Fig. 1). Since the volume of each perifusion chamber and its associated tubing was $2.8 \mathrm{ml}$, the calculated dead time of the system at the usual flow-through rate of $0.9 \mathrm{ml} / \mathrm{min}$ would be approximately $3 \mathrm{~min}$. In 25 experiments with $3 \mathrm{mg} / \mathrm{ml}$ glucose, significant $(P<0.001)$ increments in ${ }^{32} \mathrm{P}$ efflux averaging $177 \pm 16 \%$ of basal values were manifest at 4 min so that the ${ }^{32} \mathrm{P}$ response of the islets to glucose impact was virtually immediate. Peak efflux of ${ }^{32} \mathrm{P}$ occurred

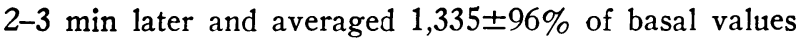
(range $700-2,100 \%$ ). Thereafter, the release of ${ }^{22} \mathrm{P}$ rapidly returned to basal values. The entire flush did not last more than $13 \mathrm{~min}$ in 25 experiments and usually 10 min or less. Analysis of the stimulated islets in four experiments showed that the flush accounted for $37.3 \pm 2 \%$ of the cellular acid-soluble ${ }^{22} \mathrm{P}$.

In further studies, after $20 \mathrm{~min}$ of perifusion with 3 $\mathrm{mg} / \mathrm{ml}$ glucose, the glucose was reduced to $0.5 \mathrm{mg} / \mathrm{ml}$ for another $20 \mathrm{~min}$ whereupon another loading of 3 $\mathrm{mg} / \mathrm{ml}$ glucose was given (Fig. 2). In each of three such experiments, the second impact of high glucose concentration induced a second flush of ${ }^{32} \mathrm{P}$ which was of smaller magnitude than the first, presumably because less radioactivity remained in the prelabeled islets. The finding was construed as evidence that depletion of all potentially dischargeable radioactivity did not account for the finite duration of the increased outflow of ${ }^{82} \mathrm{P}$ during the initial exposure to $3 \mathrm{mg} / \mathrm{ml}$ glucose. This interpretation was reinforced by examining the ${ }^{22} \mathrm{P}$ response during exposure to smaller increases in glucose concentration (Fig. 3). In three such experiments at each concentration, ${ }^{22} \mathrm{P}$ efflux peaked at $403 \pm 27 \%$ of basal values when glucose in the perifusion media was increased from 0.5 to $1.0 \mathrm{mg} / \mathrm{ml} ; 1,086 \pm 218 \%$ during 


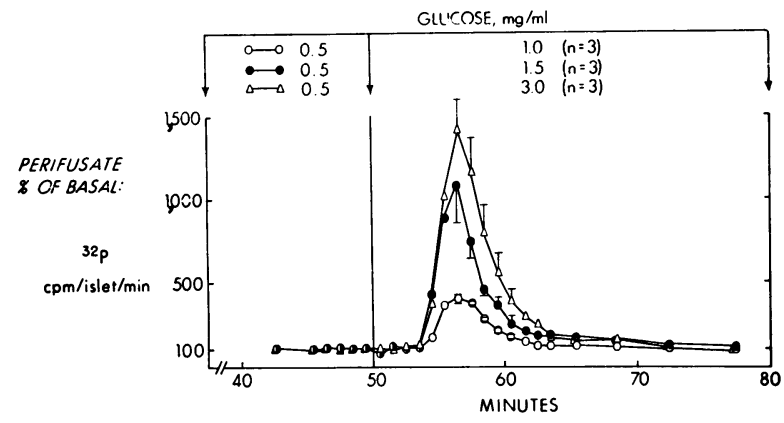

FIGURE 3 Effects of varying concentrations of glucose upon efflux of ${ }^{32} \mathrm{P}$ from prelabeled islets: After $50 \mathrm{~min}$ of perifusion with $0.5 \mathrm{mg} / \mathrm{ml}$ glucose, the concentrations of glucose in the perifusate was increased to $1.0,1.5$, or 3.0 $\mathrm{mg} / \mathrm{ml}$. Results (mean \pm SEM) at each time point have been expressed as a percentage of the "basal" values-i.e., the average counts per minute ${ }^{32} \mathrm{P}$ per islet per minute which were present in the perifusate during the 5 min preceding the increase in glucose. By this convention, basal values represent $100 \%$. $\mathrm{n}$ denotes the number of experiments.

increase from 0.5 to $1.5 \mathrm{mg} / \mathrm{ml}$; and $1,424 \pm 186 \%$ during increase from 0.5 to $3.0 \mathrm{mg} / \mathrm{ml}$ (Fig. 3). Contrariwise, basal ${ }^{32} \mathrm{P}$ outflow was not affected significantly in concurrent similar studies (not shown) in which media were changed from 0 to $0.5 \mathrm{mg} / \mathrm{ml}$ glucose. As with $3.0 \mathrm{mg} / \mathrm{ml}$, the dose-dependent heightened releases of ${ }^{22} \mathrm{P}$ in response to 1.0 and $1.5 \mathrm{mg} / \mathrm{ml}$ glucose were also evanescent (Fig. 3 ), thus indicating that these transitory ${ }^{32} \mathrm{P}$ flushes represent "packet-pulses" rather than limitations in the available radioactivity accumulated during prelabeling.

To rule out the necessity for bidirectional phosphate exchanges, phosphate buffer was omitted from the Krebs-Ringer bicarbonate solution throughout the perifusion period in three experimental runs. Heightened

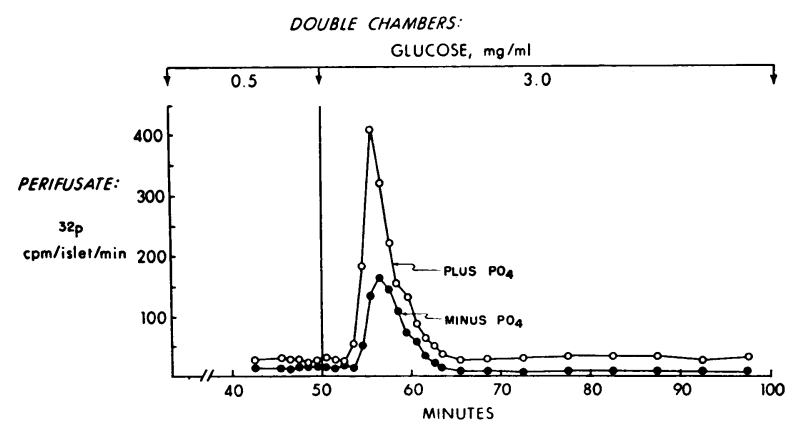

Figure 4 Effect of extracellular phosphate ion on efflux of ${ }^{22} \mathrm{P}$ during stimulation of prelabeled islets with high glucose concentration: Double chambers were employed to perifuse prelabeled islets with conventional Krebs-Ringer bicarbonate (open circles) or Krebs-Ringer bicarbonate from which ionic phosphate had been omitted (closed circles). One of three experiments is presented in the illustration.

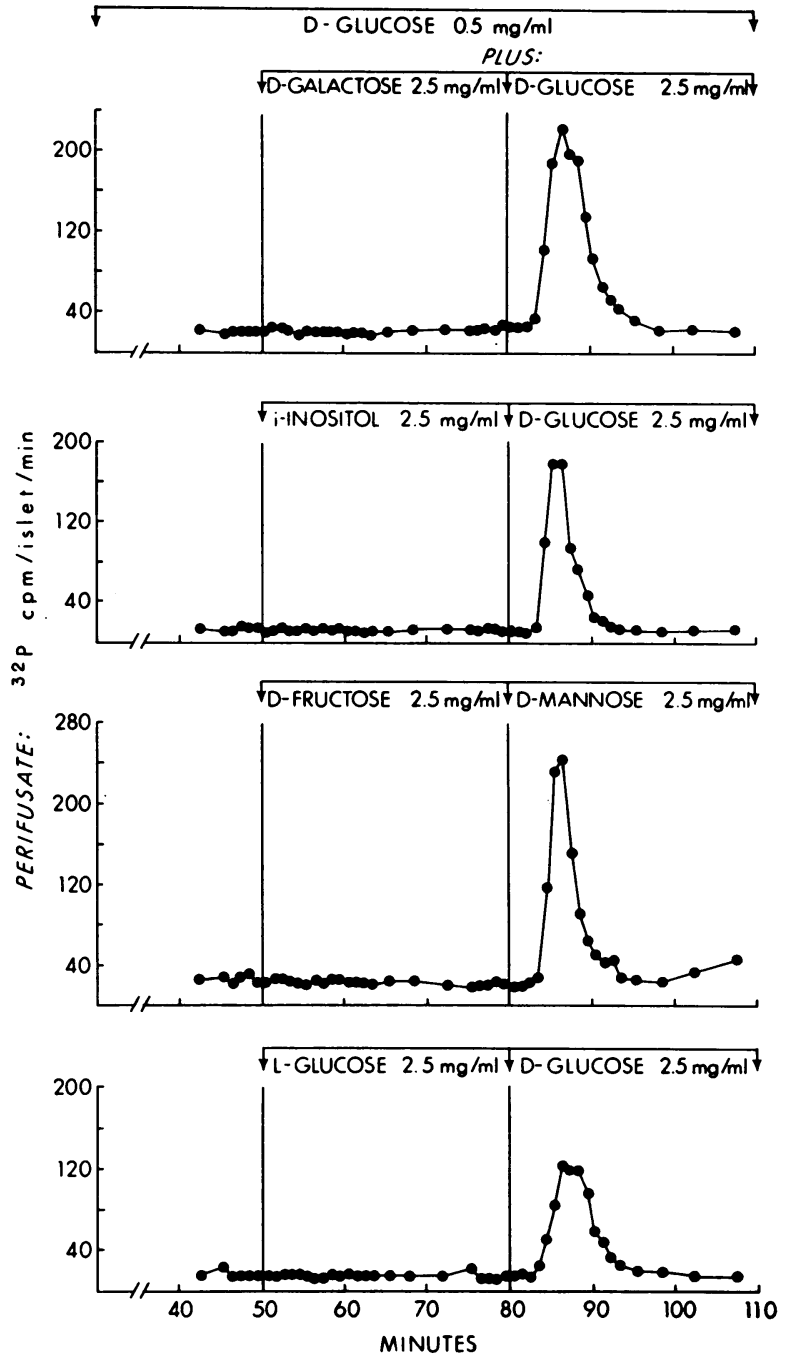

FIgURE 5 Effect of various sugars on the efflux of ${ }^{82} \mathrm{P}$ from prelabeled islets: After $50 \mathrm{~min}$ of basal perifusion with Krebs-Ringer bicarbonate containing $0.5 \mathrm{mg} / \mathrm{ml} \mathrm{D-}$ glucose, perifusates were supplemented further with 2.5 $\mathrm{mg} / \mathrm{ml}$ D-galactose, i-inositol, D-fructose, or L-glucose. Basal rates of ${ }^{82} \mathrm{P}$ efflux were unaffected. However, substitution of $2.5 \mathrm{mg} / \mathrm{ml} \mathrm{D}$-glucose or $\mathrm{D}$-mannose at $80 \mathrm{~min}$ effected prompt increase in ${ }^{32} \mathrm{P}$ efflux in all experiments.

release at ${ }^{32} \mathrm{P}$ in response to $3 \mathrm{mg} / \mathrm{ml}$ glucose was still observed although the magnitude was $32.3 \pm 9.6 \%$ less than that seen in the concurrent control studies with phosphate-supplemented medium (Fig. 4). ${ }^{2}$ Hence, ${ }^{\infty} \mathrm{P}$ efflux does not seem to require concurrent influx of orthophosphate.

${ }^{2}$ Carrier phosphate was included in all collection tubes for these experiments. Nonetheless, the possibility cannot be excluded that some of the apparent reduction of ${ }^{32} \mathrm{P}$ outflow in the absence of extracellular orthophosphate may have been due to adsorption of ${ }^{32} \mathrm{P}$ to glass and plastic surfaces. 
Nature of ${ }^{s} P$ radioactivity released. Portions of the perifusion collections containing the most radioactivity of the ${ }^{32} \mathrm{P}$ pulse from the glucose-stimulated islets were analyzed by high voltage paper ionophoresis. The entire radioactivity ran identically with an inorganic phosphate marker. The separation clearly distinguished between inorganic phosphate and adenosine nucleotides or pyrophosphate. (Mobility $\mathbf{p}_{\mathrm{i}}$ AMP 0.14, ADP 0.55, ATP $\left.0.81, \mathrm{PP}_{\mathbf{1}}=1.38\right)$. Inositol-1,2-cyclic phosphate $\left(\mathrm{M}_{\mathrm{P}_{\mathrm{i}}}\right.$ $0.76)$ and inositol-1-monophosphate $\left(\mathrm{M}_{\mathbf{P}_{\mathbf{1}}} 0.70\right)$ would have also migrated differently to inorganic phosphate. An identical result was obtained when carrier ATP, $\mathrm{ADP}$, and phosphocreatine $(4 \mu \mathrm{mol})$ were added to the collection tubes; when EDTA (10 mM) was immediately added to the effluent; or if the fractions were boiled for $1 \mathrm{~min}$ immediately on collection to eliminate postcollection enzymatic activity (no ATPase could be detected in the perifusate). Similar results were obtained when the radioactivity was separated on a paper chromatogram in phenol saturated with water-ethanolacetic acid solvent, 100:12:10 part by volume, and in the Berenblum and Chain (16) analytical procedure in which the radioactivity again predominantly reacted as inorganic phosphate.

Specificity of ${ }^{s 2} P$ release. A number of other sugars or sugar analogues were tested to see if they would bring about a similar pulse of ${ }^{32} \mathrm{P}$ from the islets as had occurred on loading with D-glucose. At a level of $2.5 \mathrm{mg} / \mathrm{ml}$, D-galactose, i-inositol, L-glucose, and $\mathrm{D}$-fructose added to a basal level of $0.5 \mathrm{mg} / \mathrm{ml} \mathrm{D}$-glucose failed to elicit a significant $\left[{ }^{32} \mathrm{P}\right]$ phosphate flush (Fig. 5). D-Glucose (2.5 $\mathrm{mg} / \mathrm{ml})$ or D-mannose $(2.5 \mathrm{mg} / \mathrm{ml})$ added after these

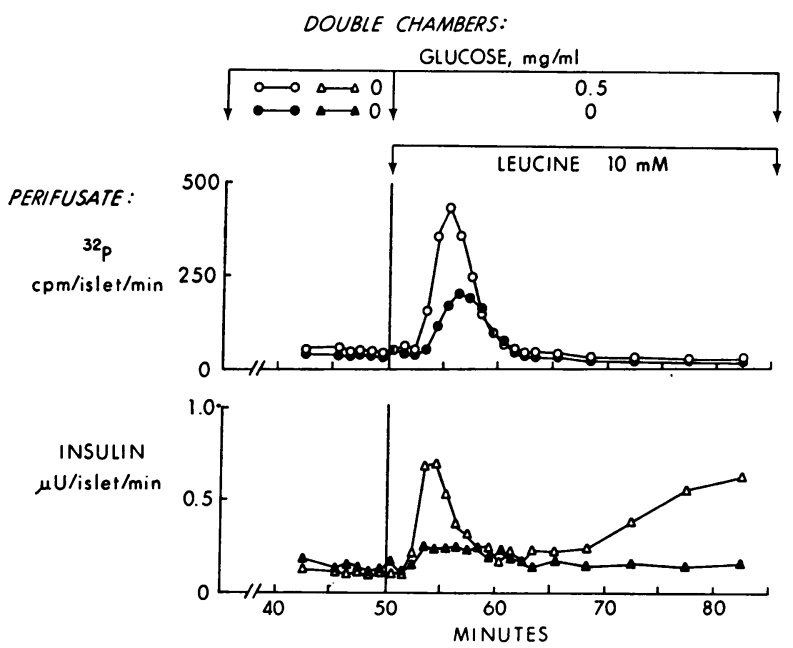

FIGURE 6 Effect of L-leucine during perifusion of prelabeled islets: The illustration depicts a representative experiment in which double chambers were employed to compare the effects of $10 \mathrm{mM}$ leucine in the absence (closed symbols) or presence (open symbols) of $0.5 \mathrm{mg} / \mathrm{ml}$ glucose.

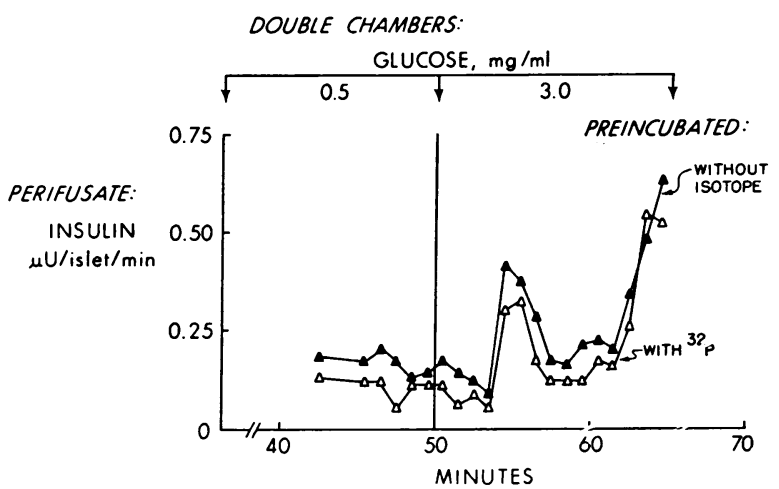

Figure 7 Effect of prior radiation on release of insulin during perifusion of isolated rat pancreatic islets: Aliquots from a preparation of islets were incubated for $90 \mathrm{~min}$ with Krebs-Ringer bicarbonate containing no isotope or $150 \mu \mathrm{Ci}$ $\left[{ }^{32} \mathrm{P}\right.$ ] orthophosphate $/ \mathrm{ml}$. Thereafter, labeled and unlabeled islets were compared during simultaneous perifusion in double chambers. One of two such experiments is shown above.

other hexoses produced the usual ${ }^{32} \mathrm{P}$ efflux. None of these sugars apart from the D-glucose and D-mannose has been shown to cause insulin release from isolated pancreatic islets (17) although it is known that $\mathrm{D}$-fructose may stimulate insulin release from intact pancreas tissue.

The amino acid, L-leucine, was examined as a secretagogue which can also stimulate insulin release but via mechanisms that are different than those for sugars. In three such experiments, to be described in detail elsewhere, inclusion of $10 \mathrm{mM}$ L-leucine in the perifusion medium elicited increased ${ }^{22} \mathrm{P}$ efflux within $4 \mathrm{~min}$. The magnitude of the ${ }^{32} \mathrm{P}$ pulse appeared to be greater when the medium also contained $0.5 \mathrm{mg} / \mathrm{ml}$ glucose than when glucose was omitted (Fig. 6).

Temporal relationships between release of phosphate and insulin. The islet perifusion technique used in these experiments involved two significant differences from those previously published: firstly, there was an additional 90 -min preincubation for labeling of the islets, and secondly, the islets were subject to substantial radiation $\left(150 \mu \mathrm{Ci}{ }^{22} \mathrm{P}\right.$ in $\left.1 \mathrm{ml}\right)$ during this incubation and to appreciable extra washings to remove adherent radioactivity thereafter. These added manipulations and delays may have accounted for our lesser magnitude of insulin release during perifusion than previously reported by Lacy et al. (10). For example, when aliquots from three different preparations of islets were perifused (a) directly after isolation as per Lacy (10) or (b) after $90 \mathrm{~min}$ preincubation (without radioactivity) and our usual series of extra washings, the comparative rates of insulin release for ( $a$ ) vs. (b) during $50 \mathrm{~min}$ of perifusion with $3.0 \mathrm{mg} / \mathrm{ml}$ glucose were 1.79 vs. $1.02 ; 2.91$ vs. 1.17 ; and 2.26 vs. $1.49 \mu \mathrm{U} /$ islet/min, respectively. The extra manipulations may also have accounted for greater 

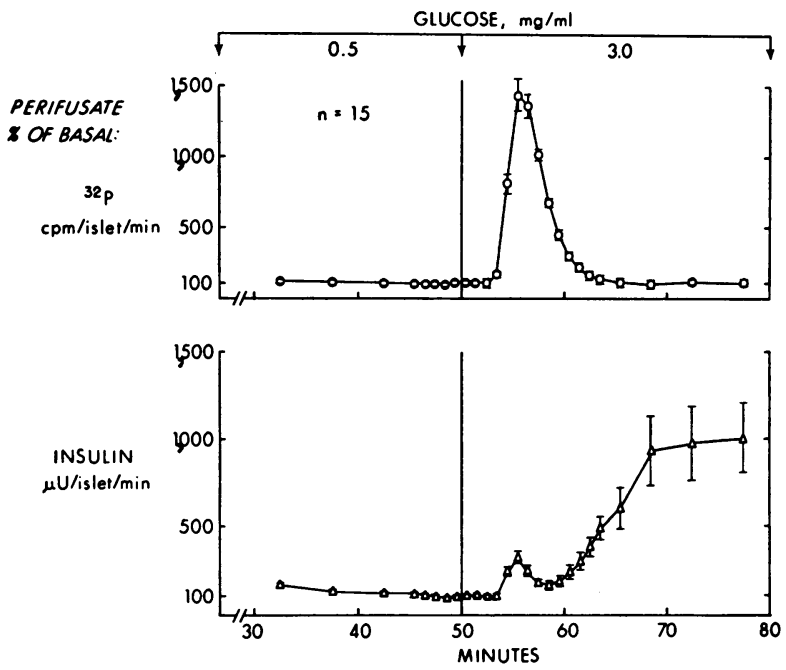

Figure 8 Temporal relationships between ${ }^{32} \mathrm{P}$ efflux and biphasic insulin secretion from prelabeled islets: Observations from 15 experiments in which $3 \mathrm{mg} / \mathrm{ml}$ glucose elicited a satisfactory first-phase insulin release were expressed as percentages of their respective basal values (i.e., derived as in Fig. 3). The illustration depicts the concurrent results (mean \pm SEM) at each time point for ${ }^{32} \mathrm{P}$ efflux and insulin secretion after stimulation with high glucose concentration.

variability in patterns of insulin secretion. Thus, we did not consistently obtain that biphasic release of insulin in response to $3.0 \mathrm{mg} / \mathrm{ml}$ glucose which Lacy et al. (10, 18) observed in a similar perifusion system-that is, a rapid primary packet pulse of insulin release followed in 8-10 min by a slower buildup of the second and more continuous phase of insulin secretion. In our hands, the first phase could be demonstrated in only about twothirds of the experiments (and did not appear to be modified by prior irradiation, Fig. 7). Failures to elicit the first phase of insulin secretion were much more frequent during our initial experiments in which Ficoll gradients were used to concentrate islets.

The magnitude of phosphate flush in response to secretory stimulants did not appear to be different in those experiments in which first phase insulin release could not be demonstrated. Therefore, heightened release of ${ }^{32} \mathrm{P}$ may be dissociated from the measurable extrusion of preformed secretory products. Nonetheless, phosphate flush and first-phase insulin release in response to 3 $\mathrm{mg} / \mathrm{ml}$ glucose were compared in 15 experiments to assess the possible temporal correlations between these two types of packet pulses. Results for both parameters, expressed as "percentages of basal values" are summarized in Fig. 8. The first phase of insulin release appeared to commence at the same time or within $1 \mathrm{~min}$ after the onset of phosphate flush but finished earlier; the second phase of stimulated insulin release began 2-4 min before the heightened efflux of ${ }^{\mathrm{P}}$ returned to basal values
(Fig. 8). Thus, precise temporal overlap does not obtain. Experiments with leucine were similar. When leucine elicited a first phase of insulin release, the duration was less than that of the concurrent phosphate flush (Fig. 6).

Effects of omitting calcium or adding nickel. Experiments with $\mathrm{Ca}^{++}$-free systems or ionic nickel were instituted in further attempts to dissociate phosphate flush and stimulated insulin secretion.

Calcium has been firmly established as an essential divalent cation required for the secretion of insulin by pancreas $\beta$-cells in response to glucose loading $(19,20)$. In four experiments, omission of all calcium ions from the medium reduced insulin secretion in response to perifusion with $3.0 \mathrm{mg} / \mathrm{ml}$ glucose by $62.3 \pm 11.2 \%$. However, ${ }^{32} \mathrm{P}$ pulse effusion was unimpaired, and in three of the four experiments, the ${ }^{32} \mathrm{P}$ efflux was greater than in the presence of normal amounts of $\mathrm{Ca}^{++}$(Fig. 9).

The addition of nickel ions $(2 \mathrm{mM})$ to the perifusate also allowed the ${ }^{32} \mathrm{P}$ efflux in response to glucose impact, although the release of insulin was abolished (Fig. 10). Nickel is known to interfere in many systems requiring calcium, perhaps, in part, by displacing $\mathrm{Ca}^{++}$from binding sites (21). Insulin secretion promptly occurred when nickel was withdrawn while the exposure to 3 $\mathrm{mg} / \mathrm{ml}$ glucose continued; a second increase in ${ }^{32} \mathrm{P}$ efflux did not occur at that time (Fig. 10).

Effect of tetracaine addition on ${ }^{\text {ss }} P$ efflux. Agents known to stabilize membranes were tested to evaluate whether ${ }^{32} \mathrm{P}$ efflux may reflect some transitory alteration in islet membrane permeability. Release of ${ }^{32} \mathrm{P}$ from islets in response to glucose still occurred in the presence of $0.2 \mathrm{mM}$ oubain, a concentration which should be suffi-

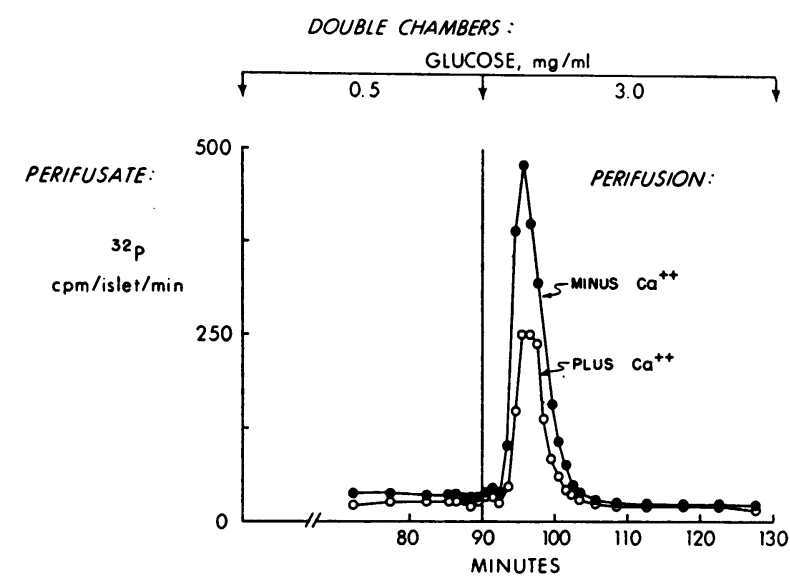

Figure 9 The effect of calcium ion on efflux of ${ }^{32} \mathrm{P}$ during secretory stimulation of prelabeled islets: One of four experiments is shown above. Double chambers were employed to perifuse prelabeled islets with Krebs-Ringer bicarbonate containing $2.4 \mathrm{mM} \mathrm{Ca}^{++}$(open circles) or Krebs-Ringer bicarbonate from which all $\mathrm{Ca}^{++}$had been omitted (closed circles). 

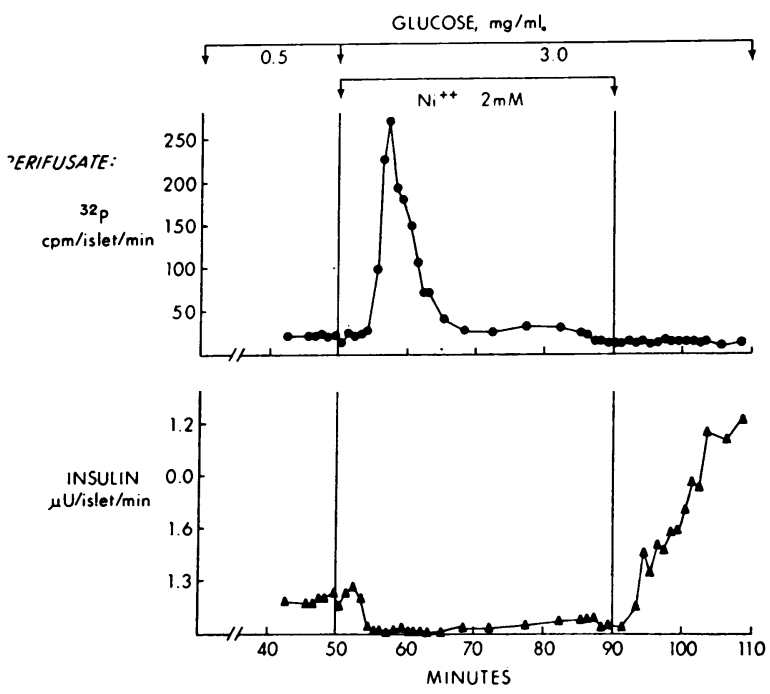

Figure 10 The effect of nickel ion on efflux of ${ }^{82} \mathrm{P}$ and insulin release during stimulation of prelabeled islets: The illustration depicts absolute values from one of three experiments; all gave similar results. Heightened efflux of ${ }^{32} \mathrm{P}$ in response to $3.0 \mathrm{mg} / \mathrm{ml}$ glucose was manifested despite the concurrent presence of $\mathrm{Ni}^{++}(2 \mathrm{mM})$ in the perifusion medium. However, augmented insulin release did not occur until $\mathrm{Ni}^{++}$was omitted from the perifusate at $90 \mathrm{~min}$.

cient to attenuate the $\mathrm{Na}, \mathrm{K}$-stimulated "transport-ATPase" of the plasma membrane of the $\beta$-cells.

Tetracaine, in concentrations $(1.0 \mathrm{mM})$ known to inhibit cyclic AMP-induced translocations of $\mathrm{Ca}^{++}$in other systems (22), almost completely suppressed the release of ${ }^{32} \mathrm{P}$ from the islets in response to glucose loading ( 3 $\mathrm{mg} / \mathrm{ml})$; when the tetracaine was then omitted from the perifusion medium and the glucose loading maintained there was a prompt efflux of ${ }^{32} \mathrm{P}$ from the islets (Fig. 11). Tetracaine also inhibited the release of insulin from the islets (not shown in the illustration), but the reversibility of this inhibition after tetracaine withdrawal was inconstant in four such experiments.

Effect of $\mathrm{D}_{2} \mathrm{O}$ on ${ }^{s 2} \mathrm{P}$ efflux. $\mathrm{D}_{2} \mathrm{O}$ is known to produce almost total inhibition of glucose-induced insulin secretion from isolated islets or segments of rat pancreas maintained in vitro $(10,23)$, presumably by producing stabilization and interference with the function of microtubules. Perifusion of ${ }^{32} \mathrm{P}$-labeled islets with a medium containing $\mathrm{D}_{2} \mathrm{O}$ instead of $\mathrm{H}_{2} \mathrm{O}$ suppressed all insulin release and obtunded ${ }^{32} \mathrm{P}$ liberation from the islets in response to $3 \mathrm{mg} / \mathrm{ml}$ glucose loading (Fig. 12). On maintaining the glucose concentration and reverting to $\mathrm{H}_{2} \mathrm{O}$ in the perifusion fluid, an immediate overshoot of insulin release was obtained as has been previously reported by Lacy et al. (10). At the same time, a ${ }^{30} \mathrm{P}$ efflux was manifest (Fig. 12).

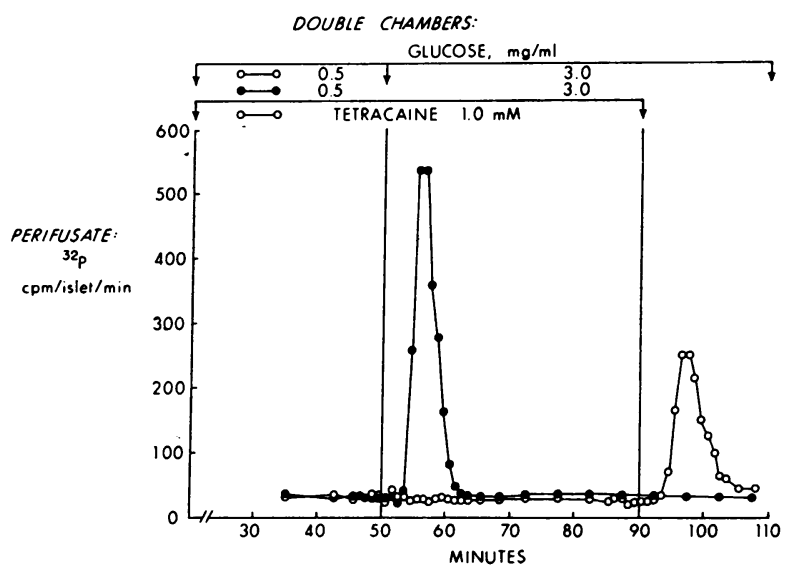

FIGURE 11 The effect of tetracaine on efflux of ${ }^{32} \mathrm{P}$ during stimulation of prelabeled islets: One of four experiments with $1.0 \mathrm{mM}$ tetracaine is shown. Double chambers were employed. In the control chamber (closed circles) perifusion was conducted with Krebs-Ringer bicarbonate containing $0.5 \mathrm{mg} / \mathrm{ml}$ glucose for the first $50 \mathrm{~min}$ and 3.0 $\mathrm{mg} / \mathrm{ml}$ glucose for the subsequent $60 \mathrm{~min}$. In the experimental chamber (open circles), the same concentrations of glucose were employed but perifusion media for the first 90 min contained $1.0 \mathrm{mM}$ tetracaine in addition.

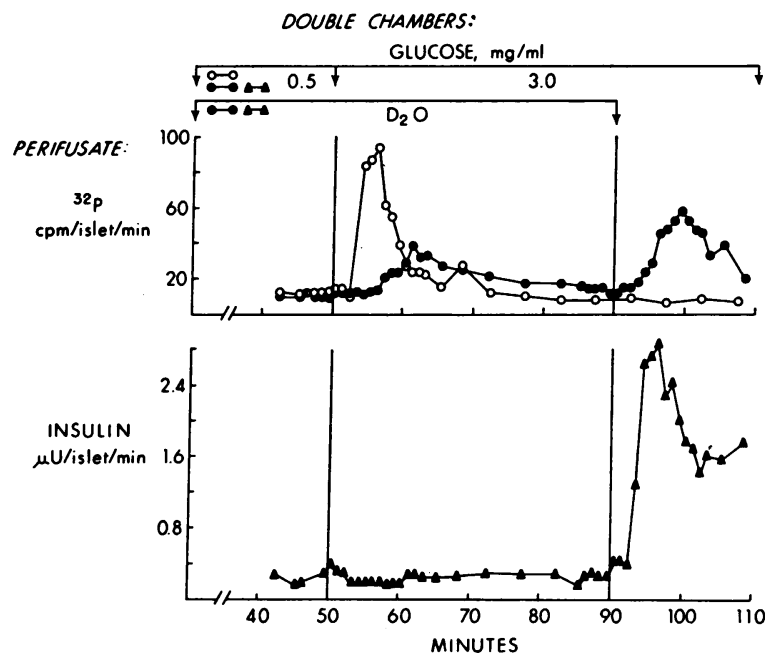

Figure 12 The effect of $\mathrm{D}_{2} \mathrm{O}$ on efflux of ${ }^{32} \mathrm{P}$ and insulin release during stimulation of prelabeled islets: Double chambers were employed. The open circles denote the pattern of ${ }^{20} \mathrm{P}$ release in the chamber perifused by the standard technic. The closed symbols denote the concurrent patterns in the second chamber perifused for $90 \mathrm{~min}$ with $\mathrm{D}_{2} \mathrm{O}$-containing media. Efflux of ${ }^{32} \mathrm{P}$ was markedly obtunded despite the presence of $3.0 \mathrm{mg} / \mathrm{ml}$ glucose. However, when conventional Krebs-Ringer bicarbonate was substituted for $\mathrm{D}_{2} \mathrm{O}$ at $90 \mathrm{~min}$, heightened release of ${ }^{32} \mathrm{P}$ was manifest together with an immediate and pronounced secretion of insulin. One of three experiments yielding essentially identical results is presented above. 


\section{DISCUSSION}

No previous attention has been paid to the movement of anions during the stimulation of insulin secretion by pancreatic islets. We have now shown that the rapid release in insulin from islets, which is known to be elicited by $3 \mathrm{mg} / \mathrm{ml} \mathrm{D}$-glucose, D-mannose, or $10 \mathrm{mM}$ leucine is clearly attended by a pulse of $\left[{ }^{32} \mathrm{P}\right]$ inorganic phosphate from the cells. It seems likely that this efflux of inorganic phosphate is associated with the excitatory state produced by the secretagogue since it does not occur if equivalent quantities of nonstimulatory sugars or their analogues such as D-galactose, L-glucose, D-fructose, or i-inositol are introduced into the perifusion medium. Although these studies do not necessarily implicate the $\beta$-cell as the cell type within the islets from which the phosphorus originates, our more recent experiences with the nonmetabolized leucine analogue, 2-aminonorbornane-2-carboxylic acid ( $\mathrm{BCH})$ strengthen that likelihood (24). To date, $\mathrm{BCH}$ has not been shown to affect islet components other than the $\beta$-cells (24a); in our hands, $\mathrm{BCH}$ triggers heightened phosphate efflux from isolated islets coincident with rapid insulin secretion (24). Thus, the ${ }^{32} \mathrm{P}$ inorganic liberation may or may not be directly involved as an essential component in those series of biochemical and biomechanical events which occur in between stimulation of the $\beta$-cell and the release of insulin.

No evidence could be obtained of the efflux of any ${ }^{32} \mathrm{P}$-labeled metabolite from the islet cells, although it is just possible that small amounts could be masked by the large $\left[{ }^{2} \mathrm{P}\right]$ inorganic phosphate release. Release of inositol cyclic phosphate or inositol monophosphate was not observed after stimulation of the islets even though substantial ${ }^{32} \mathrm{P}$ labeling of phosphatidylinositol had occurred. It is entirely possible, however, that the method is not sensitive enough to detect the release of such metabolites in very small quantities or alternatively, they may be formed in the islet cell due to the more rapid turnover of the phospholipid and not released to the perifusion medium. Release of ATP as described by Leitner et al. (25) was not observed, even when precautions were taken to avoid ATPase activity subsequent to collection of the perifusion. It is of course possible that the appropriate ATP pool in the islets had not become labeled in our experiments so that release of ATP would not have been detected.

It is not possible to deduce from the present results whether the release of ${ }^{82} \mathrm{P}$ represents a net efflux of phosphate ions from the islets or an increased exchange of tissue phosphate ions with those in the perifusion medium. When inorganic $P$ was entirely excluded from the perifusion fluid, ${ }^{32} \mathrm{P}$ release still occurred on glucose stimulation of the islets suggesting that if the phenomenon is normally a phosphate ion exchange, the efflux is not directly coupled to phosphate ion influx.
In the analogous accumulation of inorganic phosphate in sheep thyroid slices in response to thyrotropin (4), good evidence was obtained that this was derived more from catabolism of organophosphorus compounds within the tissue rather than from influx of orthophosphate from the suspending medium. However, because of the microamounts of islet tissue used in the present technique, direct analysis of the phosphorus distribution before and after stimulation was not feasible. Our preliminary analyses of the distribution of radioactivity have suggested that most of the ${ }^{32} \mathrm{P}$ released is derived from the cellular acid-soluble radioactivity. However, since radioactive equilibrium undoubtedly would not have been reached in the $90-\mathrm{min}$ labeling period, it is still possible that the $\left[{ }^{22} \mathrm{P}\right]$ phosphate liberated could arise by the stimulation releasing low specific activity water-soluble phosphate esters from phosphoproteins, phospholipids, or nucleic acids. These phosphate esters could then be decomposed by phosphatase action and consequently the low specific activity phosphate ions released would displace higher specific activity phosphate ions from the tissue pool. Nevertheless, the almost instantaneous release of $\left[{ }^{32} \mathrm{P}\right]$ phosphate from the cells on glucose stimulation is evidence against this mechanism.

It is a possibility that the inorganic phosphate released could be derived from the breakdown of ATP contained within the islets. Experiments with uncoupling agents have demonstrated that the turnover of ATP in mouse islets is extremely rapid, the level being reduced to $30 \%$ within 5 min when ATP synthesis is blocked (26). Glucose stimulation increases the oxygen consumption of isolated islets of mice (27) and therefore presumably their ATP turnover. However, although glucose is undoubtedly required for the long-term metabolic maintenance of ATP levels in islets (26), there is recent evidence that glucose stimulation of islets produces initially a dramatic fall in ATP levels, to $53 \%$ of controls in 2 $\mathrm{s}$ and $38 \%$ at $10 \mathrm{~s}$ (28). Phosphocreatine levels also fell although somewhat more slowly in conformity with this phosphate ester's role as an ATP concentration buffer. Thus, the initial response of the islets to glucose appears to be a reduction in the levels of high energy phosphates presumably via their expenditure for energydependent phosphorylations. If this decrease is connected with the efflux of $\left[{ }^{32} \mathrm{P}\right]$ phosphate from the islets, it is apparently not produced by "transport" ATPase since 0.2 $\mathrm{mM}$ oubain did not modify the ${ }^{22} \mathrm{P}$ release in response to glucose. Undoubtedly, however, $\beta$-cells would contain other ATPases not inhibited by oubain.

Although the biphasic release pattern of insulin from islets in response to secretagogues has now been well established both in vitro and in vivo (29-32), the nature of the early insulin release with which the beginning of the $\left[{ }^{32} \mathrm{P}\right]$ phosphate efflux appears to be temporally as- 
sociated has not been elucidated. Grodsky, Landahl, Curry, and Bennett (32) have proposed a two-compartment model to account for the release of insulin in which they suggest that only a small proportion (2-3\%) of the insulin stored within the pancreas is available for early release. The initial rapid phase of insulin production stimulated by glucose is attributed to the emptying of a small compartment while the slower release is attributed to insulin liberation from a larger storage compartment or the release of newly synthesized insulin or both. Unless, therefore, a very highly labeled pool of inorganic phosphate or its immediate precursor existed within the small compartment, it is difficult to believe that the $\left[{ }^{32} \mathrm{P}\right]$ phosphate flush can be associated with any cytoplasmic release during the emiocytotic liberation of the initial insulin package. This is also shown by the failure to detect insulin release in certain situations which still allow ${ }^{32} \mathrm{P}$ efflux in response to glucose loading. Examples would be the one-third of our regular experiments (and the higher percentage of our experiments with Ficoll gradients) in which we failed to elicit the first phase of insulin release with $3 \mathrm{mg} / \mathrm{ml}$ glucose despite heightened release of ${ }^{32} \mathrm{P}$. Further examples would be the invariable preservation of the phosphate flush during the general attenuation of insulin secretion that occurred with the omission of $\mathrm{Ca}^{++}$from the perifusate or the addition of $\mathrm{Ni}^{++}$to it. Nevertheless, like the early insulin release, the release of ${ }^{28} \mathrm{P}$ occurs as a limited packet pulse. Therefore, the stimulation causes an efflux of ${ }^{82} \mathrm{P}$ which then ceases although the secretagogue is still present. The phenomenon displays dose-response characteristics (Fig. 3) and can be elicited repetitively (Fig. 2) so that its finite duration during initial stimulation cannot be ascribed to depletion of potentially dischargeable radioactivity.

It seems much more likely that the release of $\left[{ }^{32} \mathrm{P}\right]$ phosphate occurs as a consequence of a membrane permeability change induced by the secretagogue. Much evidence is now accumulating that glucose exerts its initial effect on the islet cell by reacting with specific receptor sites on the plasma membrane or on an enzyme complex $(33,34)$, although an effect through its subsequent metabolism cannot entirely be discounted (1). However, present indications would suggest that a single receptor site glucoreceptor model may be inadequate to account for all types of stimulation of the pancreas cell, particularly by leucine. Secretagogues cause significant electrical effects on the cell membranes of islets prepared by microdissection by causing successive small action potentials superimposed on an inside membrane resting potential of approximately $-20 \mathrm{mV}$ in the mouse (35$37)$. There is much evidence that the frequency of these action potentials parallels changes in the secretion of insulin by the $\beta$-cell brought about by various agents. It seems possible therefore that stimulation of insulin release may be mediated by changes in the ion permeability of the membranes and that the observed changes in electrical activity reflect these alterations in permeability. If similar electrical changes occur with collagenasetreated islets, the increased flux of phosphate ions through their membranes may be one of the manifestations of such permeability changes.

In mitochondria, fluxes of phosphate ions appear to be directly coupled to $\mathrm{H}^{+}$movement and the concentrations of both of these ions is probably intimately related to the level of $\mathrm{Ca}^{++}(38,39)$. In this connection it is generally assumed that calcium ions may increase in intracellular concentration very early in islet cell stimulation, possibly by a reduction in the rate of efflux of $\mathrm{Ca}^{++}(40,41)$, but this is followed by an increased $\mathrm{Ca}^{++}$efflux during the rapid phase of insulin secretion (42). Thus, the efflux of phosphate observed is probably occurring at the same time as an efflux of $\mathrm{Ca}^{++}$. However, the two movements can be dissociated since, whereas in the absence of calcium in the external medium the efflux of $\mathrm{Ca}^{++}$from the islet in response to glucose is prevented (42), the release of $\mathrm{PO}_{4}$ ions is if anything enhanced. Moreover, in the present experiments the addition of $\mathrm{Ni}^{++}$, an antagonist of $\mathrm{Ca}^{++}$, results in no marked decrease in the efflux of $\left[{ }^{32} \mathrm{P}\right]$ phosphate.

In the absence of external calcium, the increased electrical activity in the islet membrane stimulated by glucose is considerably reduced (37) whereas the ${ }^{32} \mathrm{P}$ efflux is not.

Although at first sight this would suggest that the ${ }^{82} \mathrm{P}$ outflow is not related to changes in membrane permeability, it could well be that the secretagogue still causes such changes but that these are not manifest in electrical action potentials unless a translocation of $\mathrm{Ca}^{++}$is possible. In this connection, it is perhaps surprising that tetracaine in low concentrations should inhibit ${ }^{22} \mathrm{P}$ efflux so completely. One of the actions of this lipophilic local anesthetic is to displace $\mathrm{Ca}^{++}$from membranes (43), although other effects are distinctly possible. It may be that because of the hydrophobic regions of its molecule, tetracaine can penetrate and displace $\mathrm{Ca}^{++}$from parts of the islet cell which are not affected by external $\mathrm{Ca}^{++}$ deprivation or $\mathrm{Ni}^{++}$addition.

While the phosphate release from the islet cells in response to insulin secretion commences at the same time or slightly earlier than the first phase of insulin release, and like the latter is self-limiting, there is no clear indication one way or another whether it is directly connected with the mechanism of islet cell excitation and insulin secretion. Both releases are elicited by known secretagogues of insulin such as D-glucose, D-mannose, or L-leucine and not by closely related sugars or their analogues such as D-galactose, D-fructose, L-glucose, or 
i-inositol. However, even if the phosphate release is directly involved in the secretion of insulin, it is not to be expected that the two phenomena would exactly parallel each other in all experimental situations. Insulin secretion represents a chain of events which is initiated by the original excitation. Interruption of one of these events will not necessarily mean that phenomena observed at an early stage in the process will be inhibited. The absence of an effect of calcium deprivation or $\mathrm{Ni}^{++}$addition on ${ }^{32} \mathrm{P}$ efflux while inhibition of insulin secretion is observed does not necessarily mean that the two events are unconnected. The prompt reversal of the inhibited insulin release, without further phosphate flush, as when $\mathrm{Ni}^{++}$is withdrawn, might merely indicate that ionic nickel had inhibited some component of the secretory sequence distal to that which had been triggered already to effect heightened ${ }^{32} \mathrm{P}$ release. Within this framework it is, in fact, rather surprising that $\mathrm{D}_{2} \mathrm{O}$ inhibits $\left[{ }^{32} \mathrm{P}\right]$ phosphate efflux since one would assume that this exhibits its inhibitory effect at a late stage of insulin secretion, namely the microtubular system involved in the mechanical extrusion of the insulin containing granules from the cells. However, it is likely that $\mathrm{D}_{2} \mathrm{O}$ through a general inhibition of hydrogen bonding (44) may also stabilize the structural organization of the lipoproteins in the plasma membrane and thus suppress changes in permeability usually brought about by the secretagogue.

\section{ACKNOWLEDGMENTS}

The authors are deeply grateful to Dr. Paul Lacy for his generous advice in establishing the perifusion technique in this laboratory. The assistance of Dr. Susan Heim Ford in our early experiments is also appreciated.

This work was supported in part by Research Grant AM-10699 and Training Grant AM-05071 from the National Institute of Arthritis and Metabolic Diseases, National Institutes of Health, Bethesda, Md.

\section{REFERENCES}

1. Randle, P. J., and C. N. Hales. 1972. Insulin release mechanisms. The endocrine pancreas. Handb. Physiol. 1 (Sect. 7) : 219-235.

2. Freinkel, N., and N. Cohanim. 1972. Islet phospholipogenesis and glucose-stimulated insulin secretion. J. Clin. Invest. $51: 33 a$. (Abstr.)

3. Freinkel, N. 1957. Pathways of thyroidal phosphorus metabolism. The effect of pituitary thyrotropin upon the phospholipids of the sheep thyroid gland. Endocrinology. 61 : 448-460.

4. Freinkel, N. 1963. Action of pituitary thyrotropin on the inorganic phosphorus of thyroid tissue in vitro. Nature (Lond.). 198: 889-891.

5. Abood, L. G., K. Koketsu, and I. Koyama. 1961. Outflux of inorganic and organic phosphate during membrane depolarization of excitable tissues. Nature (Lond.). 191 : 395-396.

6. Lapetina, E. G., and R. H. Michell. 1973. Phosphatidylinositol metabolism in cells receiving extracellular stim- ulation. FEBS (Fed. Eur. Biochem. So:.) Lett. 31: 1-10.

7. Jungalwala, F. B., N. Freinkel, and R. M. C. Dawson. 1971. The metabolism of phosphatidylinositol in the thyroid gland of the pig. Biochem. J. 123: 19-33.

8. Dawson, R. M. C., N. Freinkel, F. B. Jungalwala, and N. Clarke. 1971. The enzymic formation of myoinositol1:2-cyclic phosphate from phosphatydilinositol. Biochem. J. 122: 605-607.

9. Lacy, P. E., and M. Kostianovsky. 1967. Method for the isolation of intact islets of Langerhans from the rat pancreas. Diabetes. 16: 35-39.

10. Lacy, P. E., M. M. Walker, and C. J. Fink. 1972. Perifusion of isolated rat islets in vitro. Participation of the microtubular system in the biphasic release of insulin. Diabetes. 21 : 987-998.

11. Malaisse-Lagae, F., and W. J. Malaisse. 1971. Stimulussecretion coupling of glucose-induced insulin release. III. Uptake of ${ }^{45} \mathrm{Calcium}$ by isolated islets of Langerhans. Endocrinology. 88: 72-80.

12. Ballinger, W. F., and P. E. Lacy. 1972. Transplantation of intact pancreatic islets in rats. Surgcry (St. Louis). $72: 175-186$.

13. Beigelman, P. M., M. J. Shu, and L. T. Thomas, Jr. 1973. Insulin from individual isolated mouse islet of Langerhans. Biochem. Med. 7 : 91-96.

14. Getz, G. S., S. Jakovcic, J. Heywood, J. Frank, and M. Rabinowitz. 1970. A two-dimensional thin-layer chromatographic system for phospholipid separation. The analysis of yeast phospholipids. Biochim. Biophys. Acta. 218: 441-452.

15. Desbuquois, G., and G. D. Aurbach. 1971. Use of polyethylene glycol to separate free and antibody-bound peptide hormones in radioimmunoassays. J. Clin. Endocrinol. Mctab. 33 : 732-738.

16. Berenblum, I., and E. B. Chain. 1938. An improved method for the colorimetric determination of phosphate. Biochem. J. 32: 295-308.

17. Montague, W., and K. W. Taylor. 1968. Pentitols and insulin release by isolated rat islets of Langerhans. Biochem. J. 109 : 333-339.

18. Lacy, P. E., N. J. Klein, and C. J. Fink. 1973. Effect of cytochalasin $\mathrm{B}$ on the biphasic release of insulin in perifused rat islets. Endocrinology. 92: 1458-1468.

19. Grodsky, G. M., and L. L. Bennett. 1966. Cation requirements for insulin secretion in the isolated perfused pancreas. Diabetes. 15: 910-913.

20. Milner, R. D. G., and C. N. Hales. 1967. The role of calcium and magnesium in insulin secretion from rabbit pancreas studied in vitro. Diabetologia. 3: 47-49.

21. LaBella, F., R. Dular, S. Vivian, and G. Queen. 1973. Pituitary hormone releasing or inhibiting activity of metal ions present in hypothalamic extracts. Biochem. Biophys. Res. Commun. 52: 786-791.

22. Friedmann, N. 1972. Effect of glucagon and cyclic AMP on ion fluxes in the perfused liver. Biochim. Biophys. Acta. 274: 214-225.

23. Malaisse, W. J., F. Malaisse-Lagae, M. O. Walker, and P. E. Lacy. 1971. The stimulus-secretion coupling of glucose-induced insulin release. V. The participation of a microtubular-microfilamentous system. Diabctes. 20: 257-265.

24. Freinke1, N., C. E1 Younsi, H. N. Christensen, and R. M. C. Dawson. 1974. Effect of non-metabolizable amino acids on "phosphate flush" from isolated pancreatic 
islets. Program of the 56th Annual Meeting, The Endocrine Society, 14 June 1974. A-191. (Abstr. 271.)

24a. Fajans, S. S., R. Quibrera, S. Pek, J. C. Floyd, Jr., H. N. Christensen, and J. W. Conn. 1971. Stimulation of insulin release in the dog by a nonmetabolizable amino acid. Comparison with leucine and arginine. $J$. Clin. Endocrinol. Metab. 33: 35-41.

25. Leitner, J. W., D. Tse, D. Toothaker, R. Koerker, F. H. Schneider, and K. E. Sussman. 1973. Concomitant release of ATP and insulin from perifused isolated rat islets. Diabetes. 22: 297. (Abstr.)

26. Ashcroft, S. J. H., L. C. C. Weerasinghe, and P. J. Randle. 1973. Interrelationship of islet metabolism, adenosine triphosphate content and insulin release. Biochem. J. $132: 223-231$.

27. Hellerström, C. 1967. Effects of carbohydrates on the oxygen consumption of isolated pancreatic islets of mice. Endocrinology. 81 : 105-112.

28. Mayhew, D. A., and B. E. Corkey. 1972. Metabolic responses of pancreatic islets and the duct-ligated pancreas to glucose. Diabetes. 21: 344-345. (Abstr.)

29. Curry, D. L., L. L. Bennett, and G. M. Grodsky. 1968. Dynamics of insulin secretion by the perfused rat pancreas. Endocrinology. 83: 572-584.

30. Cerasi, F., and R. Luft. 1969. The plasma insulin response to glucose infusion in healthy subjects and in diabetes mellitus. Acta Endocrinol. 55: 278-304.

31. Porte, D., Jr., and A. A. Pupo. 1969. Insulin response to glucose. Evidence for a two pool system in man. J. Clin. Invest. 48: 2309-2319.

32. Grodsky, G. M., H. Landahl, D. Curry, and L. Bennett. 1970. A two-compartmental model for insulin secretion. In Early Diabetes. R. Camerini-Davalos and $\mathrm{H}$. S. Cole, editors. Academic Press, Inc., New York. 45-50.

33. Price, S. 1973. Pancreatic islet cell membranes: extraction of a possible glucoreceptor. Biochim. Biophys. Acta. 318: $459-463$.
34. Matschinsky, F. M., and J. Ellerman. 1973. Dissociation of the insulin releasing and the metabolic functions of hexoses in islets of Langerhans. Biochem. Biophys. Res. Commun. 50: 193-199.

35. Dean, P. M., and E. K. Matthews. 1968. Electrical activity in pancreatic islet cells. Nature (Lond.). 219: 389-390.

36. Dean, P. M., and E. K. Matthews. 1970. Glucoseinduced electrical activity in pancreatic islet cells. $J$. Physiol. (Lond.). 210: 255-264.

37. Pace, C. S., and S. Price. 1972. Electrical responses of pancreatic islet cells to secretory stimuli. Biochem. Biophys. Res. Commun. 46: 1557-1563.

38. McGivan, J. D., and M. Klingenberg. 1971. Correlation between $\mathrm{H}^{+}$and anion movement in mitochondria and the key role of the phosphate carrier. Eur. J. Biochem. $20: 392-399$.

39. Rasmussen, H., D. B. P. Goodman, and A. Tenenhouse. 1972. The role of cyclic AMP and calcium in cell activation. CRC Crit. Rev. Biochem. 1: 95-148.

40. Malaisse, W. J. 1972. Role of calcium in insulin secretion. Isr. J. Med. Sci. 8: 244-251.

41. Brisson, G. R., and W. J. Malaisse. 1973. The stimulussecretion coupling of glucose-induced insulin release. XI. Effects of theophylline and epinephrine on ${ }^{45} \mathrm{Ca}$ efflux from perifused islets. Metab. (Clin. Exp.). 22: 455-465.

42. Malaisse, W. J., G. R. Brisson, and L. E. Baird. 1973. Stimulus-secretion coupling of glucose-induced insulin release. X. Effect of glucose on ${ }^{45} \mathrm{Ca}$ efflux from perifused islets. Am. J. Physiol. 224 : 389-394.

43. Hauser, H., and R. M. C. Dawson. 1968. The displacement of calcium ions from phospholipid monolayers by pharmacologically active and other organic bases. Biochem. J. 109: 909-916.

44. Bigeleisen, J. 1965. Chemistry of isotopes. Science (Wash. D. C.). 147 : 463-471. 